УДК 342.9

DOI https://doi.org/10.32849/2663-5313/2020.3.24

Ірина Желтобрюх,

канд. юрид. наук,

суддя Верховного Суду

\title{
ЗАХОДИ ПРОЦЕСУАЛЬНОГО ПРИМУСУ, ЩО ЗАСТОСОВУЮТЬСЯ ДО СТОРІН У СПРАВІ ЗА ЗАКОНОДАВСТВОМ ПРО АДМІНІСТРАТИВНЕ СУДОЧИНСТВО: ШЛЯХИ ОПТИМІЗАЦЇ МАТЕРІАЛЬНО-ПРАВОВИХ ПІДСТАВ
}

у статті зауважується, що заходами проиесуального примусу, які застосовуються до сторін у справі за законодавством про адміністративне судочинство, $\epsilon:$ 1) попередження; 2) видалення із залу судового засідання; 3) тимчасове вилучення доказів для дослідження судом; 4) привід;5) штраф. Зловживання сторонами прочесуальними правами відповідно до вітчизняного законодавства про адміністративне судочинство може тягнути за собою: 1) залишення без розгляду або повернення скарги, заяви, клопотання; 2) покладення судових витрат повністю або частково незалежно від результатів вирішення спору на сторону чи ї представника; 3) постановлення окремої ухвали насамперед у разі зловживання прочесуальними правами адвокатом або прокурором з ї надісланням органу, до повноважень якого належить притягнення до дисииплінарної відповідальності прокурора або адвоката відповідно; 4) штраф.

Разом із тим обгрунтовуються декілька висновків щодо недоліків матеріально-правових підстав цих примусових заходів. Зокрема, стверджується, що видалення сторони у справі із залу судового засідання насамперед за умови, що вона веде справу самостійно, без залучення представника, унеможливлює реалізачію нею процесуальних прав під час судового засідання, що є несумісним із приниипами змагальності сторін та гласності судового проиесу, що підриває справедливість судового розгляду. Крім того, несумісною з правилом про недопущення подвійної юридичної відповідальності є можливість застосування процесуального штрафу та адміністративного штрафу за прояв неповаги до суду за одне й те саме правопорушення. Також звертається увага на те, шо вітчизняне законодавство та судова практика не містять критеріӥв, керуючись якими суд має визначати, чи накладати грошове стягнення лише на сторону у справі, чи лише на ї представника, чи на їх обох одночасно. Більше того, має місце прогалина стосовно періоду, протягом якого особа може виправити допущене порушення для подальшого скасування судом ухвали про стягнення штрафу.

Ключові слова: заходи процесуального примусу, штраф, попередження, видалення із залу судового засідання, залишення без розгляду або повернення скарги, заяви, клопотання.

Постановка проблеми. Справедлива судова процедура неодмінно має доповнюватись положеннями, що дозволяють відмежувати правомірне від протиправного користування процесуальними правами, а також примусовими засобами, за допомогою яких можна зобов'язати безпосередньо виконувати процесуальні правила та справляти каральний, превентивний та виховний вплив на порушника процесуальних правил. У зв'язку з цими міркуваннями під час реалізації та вдосконалення концепції адміністративного судочинства у вітчизняній правовій системі були переглянуті, серед іншого, склад та матеріально-правові підстави застосування заходів процесуального примусу до сторін у справі. Разом із тим аналіз вітчиз- няного законодавства про адміністративне судочинство дозволяе стверджувати, що вони не $є$ оптимальними.

Метою статті $\epsilon$ наукове опрацювання та пошук шляхів удосконалення норм законодавства щодо матеріально-правових підстав застосування заходів процесуального примусу в адміністративному судочинстві.

Аналіз публікацій. Ознайомившись із науковими джерелами, присвяченими тим чи іншим аспектам матеріально-правових підстав застосування заходів процесуального примусу до сторін у справі за законодавством про адміністративне судочинство, слід зазначити, що значний внесок в опрацювання цих 
аспектів зробили, зокрема, М. Джафарова, I. Завальнюк, О. Кузьменко та О. Панченко, В. Кузьменко, В. Пастернак, Р. Рід, Р. Річмонд, П. Талмадж.

Виклад основного матеріалу. Розпочинаючи дослідження заходів процесуального примусу, дістанемо певне розуміння сутності та призначення заходів процесуального примусу, ознайомившись із загальними положеннями законодавства про адміністративне судочинство щодо заходів процесуального примусу та науковими дослідженнями відповідного профілю.

Так, за визначенням, наведеним у ч. 1 ст. 144 Кодексу адміністративного судочинства України (далі - КАС України), заходами процесуального примусу є процесуальні дії, що вчиняються судом у визначених цим Кодексом випадках з метою спонукання відповідних осіб до виконання встановлених у суді правил, добросовісного виконання процесуальних обов'язків, припинення зловживання правами та запобігання створенню протиправних перешкод у здійсненні судочинства [1].

Зазначене визначення цілком узгоджується з тими, що напрацьовані вітчизняними вченими-адміністративістами. Зокрема, О. Кузьменко дотримується точки зору, згідно з якою заходи процесуального примусу - це нормативно визначені способи офіційного впливу суддів на осіб, які порушують встановлені у суді правила або протиправно перешкоджають здійсненню адміністративного судочинства [2, с. 31]. Так само, на переконання В. Кузьменка, заходи процесуального примусу є передбаченими законом процесуальними засобами державно-правового примусу, які застосовуються уповноваженими на те органами (посадовими особами, судом), що ведуть процес, у чітко визначеному законом порядку щодо осіб, які залучаються до адміністративно-процесуальної діяльності, для попередження і припинення їх неправомірних дій, виявлення і закріплення доказів, з метою успішного вирішення завдань адміністративного судочинства [3, с. 7]. І. Завальнюк пропонує розуміти заходи процесуального примусу в адміністративному судочинстві як превентивні заходи, які застосовуються судом для припинення протиправних дій чи бездіяльності або для запобігання їх негативним наслідкам задля забезпечення саме своєчасного захисту прав, свобод та інтересів фізичних осіб, прав та інтересів юридичних осіб від порушень збоку суб'єктів владних повноважень [4]. Також заходи процесуального примусу в адміністративному судочинстві визначають як передбачені адміністративно-процесуаль- ним законодавством засоби впливу фізичного, психологічного або майнового характеру, які застосовуються судом (головуючим суддею) або за його дорученням іншими уповноваженими особами до учасників судового процесу та інших осіб, що присутні у залі судового засідання, з метою попередження і припинення зловживання процесуальними правами, запобігання створенню протиправних перешкод у відправленні судочинства та реалізації його принципів, а також забезпечення дотримання встановлених у суді правил ведення судового процесу [5, с. 147].

Принагідно зауважимо, що за правовою доктриною країн загального права суд має вроджене та невід'ємне право вживати заходів, коли має місце зловживання процесуальними правами або з інших причин справедливий судовий розгляд стає неможливим [6, с. 10]. Інакше кажучи, можливість судів накладати санкції на сторін та їх представників за порушення правил судочинства походить не лише від наділення їх відповідними повноваженнями позитивним законодавством, але й від їхніх внутрішніх природних властивостей, що зумовлюють їх владу над поведінкою учасників справ, регулюючи її для досягнення мети правосуддя. Більше того, природними повноваженнями суду прийнято обгрунтовувати його можливість розробляти нові санкції за порушення процесуальних правил. Водночас пануючою у країнах загального права є думка про те, що, якщо закон передбачає відповідальність за той чи інший проступок, суд, як правило, не має спиратись на природні повноваження, а керуватись положеннями законодавства, або, відступаючи від них, навести грунтовне пояснення цього рішення із посиланням на особливості справи. При цьому робиться великий наголос на тому, що суди мають виявляти обачність та стриманість під час здійснення влади над поведінкою учасників справ, застосовуючи до них заходи впливу лише за цілеспрямоване ухилення від виконання законних вказівок суду та інші недобросовісні вчинки незалежно від того, чи містять вони ознаки прояву неповаги до суду [7, c. 227-228].

Взявши до уваги вищевикладене та обміркувавши призначення заходів процесуального примусу, маємо можливість констатувати, що загальною метою їх, як й інших інструментів законодавства про адміністративне судочинство, є забезпечення справедливого, неупередженого та своєчасного вирішення судом спорів у сфері публічно-правових відносин з метою ефективного захисту прав, свобод та інтересів фізичних осіб, прав та інтересів юридичних 
осіб від порушень з боку суб'єктів владних повноважень. Конкретний внесок заходів процесуального примусу у виконання завдання адміністративного судочинства проявляється в тому, що вони насамперед:

- спонукають відповідних осіб до виконання встановлених у суді правил, добросовісного виконання процесуальних обов'язків;

- припиняють зловживання правами, не допускаючи безпідставного використання судів для досягнення цілей, що не є сумісними із правосуддям, зменшуючи операційне навантаження на суди та витрати бюджетних коштів на утримання судів, а також унеможливлюючи прийняття справ до провадження та їх судового розгляду без достатніх для цього фактичних та правових підстав;

- запобігають створенню протиправних перешкод у здійсненні судочинства, відраджуючи учасників справи та причетних до справи осіб від повторення процесуальних правопорушень (спеціальна превенція), а також справляючи виховний вплив на учасників адміністративного судочинства (загальна превенція);

- можуть слугувати засобом компенсації втрат держави та учасників справи від зловживання процесуальними правами чи іншого процесуального правопорушення [8, c. 437, 445].

Разом із тим слід мати на увазі те, що станом натепер за законодавством України компенсаторна функція не властива заходам процесуального примусу, за якими закріплюється явно виражена каральна та превентивно-виховна спрямованість, тоді як заходи відповідальності за зловживання процесуальними правами, які не належать за законодавчою класифікацією до заходів процесуального примусу, нерідко слугують засобом компенсації втрат держави та учасників справи від зловживання процесуальними правами.

Визначивши сутність та призначення заходів процесуального примусу, детально опрацюємо найбільш важливі практикоприкладні питання, пов'язані із застосуванням заходів процесуального примусу, серед яких - склад та зміст заходів процесуального примусу, що знайшли своє відображення у положеннях вітчизняного законодавства про адміністративне судочинство та правовій доктрині, а також деякі засадничі аспекти порядку застосування заходів процесуального примусу.

Висвітлюючи склад та зміст заходів процесуального примусу, що можуть застосовуватись до сторін у справі, виступаючи тим самим складником їхнього адміністративнопроцесуального статусу, зазначимо, що від- повідно до класифікації вітчизняного законодавства про адміністративне судочинство за зловживання процесуальними правами та вчинення інших правопорушень до сторін у справі можуть застосовуватись такі заходи процесуального примусу:

- попередження (ст. 146 КАС України);

- видалення із залу судового засідання (ст. 146 КАС України);

- тимчасове вилучення доказів для дослідження судом (ст. 147 КАС України);

- привід (ст. 148 КАС України);

- штраф (ст. 149 КАС України) [1].

На додаток до того у цій частині дослідження розглядатимуться відмінні від установлених законодавством заходів процесуального примусу заходи відповідальності за зловживання процесуальними правами, якими, як було зазначено вище, є залишення без розгляду або повернення скарги, заяви, клопотання (ч. 3 ст. 45 КАС України), покладення судових витрат повністю або частково незалежно від результатів вирішення спору на сторону чи ії̈ представника, що зловживали процесуальними правами (ч. 8 ст. 139 КАС України), постановлення окремої ухвали насамперед у разі зловживання процесуальними правами адвокатом або прокурором із iї надісланням органу, до повноважень якого належить притягнення до дисциплінарної відповідальності прокурора або адвоката відповідно (ч. 3 ст. 249 КАС України).

Так, ознайомившись із нормативно-правовою основою застосування попередження та видалення із залу судового засідання як заходів процесуального примусу у адміністративному судочинстві, маємо можливість констатувати те, що за змістом ч. 1 ст. 146 КАС України до учасників судового процесу за порушення порядку під час судового засідання або невиконання ними розпоряджень судді (головуючого судді) застосовується попередження, а в разі повторного вчинення таких дій - видалення із залу судового засідання [1].

3 наукових праць, що зачіпають питання застосування попередження як заходу процесуального примусу, випливає, що попередження прийнято розуміти як звернене до учасника судового процесу або особи, яка $є$ присутньою у судовому засіданні, та оформлене ухвалою суду зауваження про неприпустимість допущеного цією особою порушення порядку під час судового засідання або невиконання ними розпоряджень судді (головуючого судді) та необхідність утриматись від таких вчинків під час подальшого розгляду справи. Попередження спрямоване на те, щоб чинити нервово-емоційний та інтелектуальний вплив на особистість 
особи, яка допустила порушення порядку під час судового засідання або не виконала розпорядження судді (головуючого судді), спонукаючи ії̈ до дотримання правил поведінки під час здійснення судочинства під загрозою застосування до неї більш жорстких заходів $[3$, c. $10 ; 5$, c. 83$]$.

Видалення із залу судового засідання, як справедливо стверджує М. Джафарова, полягає у позбавленні особи-порушника можливості порушувати встановлений порядок і вчиняти протиправні діяння повторно, як наслідок, сприяє забезпеченню оптимальних умов для продовження судового розгляду справи [5, с. 83]. Водночас не викликає сумнівів обгрунтованість позиції В. Пастернака щодо того, що видалення із залу судового засідання має чи не найбільше потенційних негативних наслідків. Із посиланням на прецедентне право ЄСПЛ вчений вказує на те, що позбавлення особи можливості фактично бути присутнім під час вирішення судом питання, яке стосується прав відповідної особи, є неприйнятним. Застосування судом заходу процесуального примусу у вигляді видалення із залу судового засідання до осіб, які зацікавлені в процесі розгляду справи, певною мірою може порушувати принцип гласності судового процесу, оскільки у разі видалення однієї зі сторін із судового засідання вона може бути позбавлена права на інформацію щодо часу, місця та інших обставин розгляду своєї справи [9, с. 136]. Поділяючи це переконання вченого, зауважимо, що видалення сторони у справі із залу судового засідання, насамперед за умови, що вона веде справу самостійно, без залучення представника, унеможливлює реалізацію нею процесуальних прав під час судового засідання що є несумісним із принципами змагальності сторін та гласності судового процесу, що підриває справедливість судового розгляду у цілому та визначає необхідність запровадження альтернативних видаленню із залу судового засідання примусових заходів до сторін у справі, що допустили повторне після попередження порушення порядку під час судового засідання або невиконання розпоряджень судді (головуючого судді).

Наступним заходом процесуального примусу, який характеризується універсальністю, простотою та значною сферою застосування й набуває все більшого поширення у практиці адміністративних судів, через що потребує докладного дослідження, є штраф.

Накладення на учасників справи некомпенсаторних монетарних санкцій, таких як штраф, вважається найменш суворим, але досить ефективним заходом, відсутність якого змушували б суди вдаватись до санк- цій зі значно більш масштабними наслідками (залишення позову без розгляду, направлення подання про притягнення представника до дисциплінарної відповідальності тощо) [10, с. 1071].

У відповідних положеннях законодавства про адміністративне судочинство зазначено, що суд може постановити ухвалу про стягнення в дохід Державного бюджету України з відповідної особи штрафу:

а) у сумі від 0,3 до 3 розмірів прожиткового мінімуму для працездатних осіб у випадках:

- невиконання процесуальних обов'язків, зокрема ухилення від вчинення дій, покладених судом на учасника судового процесу;

- зловживання процесуальними правами, вчинення дій або допущення бездіяльності з метою перешкоджання судочинству;

- неповідомлення суду про неможливість подати докази, витребувані судом, або неподання таких доказів без поважних причин суб'єктом владних повноважень;

- використання під час процедури врегулювання спору за участю судді портативних, аудіотехнічних пристроїв, а також здійснення фото- і кінозйомки, відео-, звукозапису;

б) від 1 до 10 розмірів прожиткового мінімуму для працездатних осіб у випадках:

- повторного чи систематичного невиконання процесуальних обов'язків;

- неодноразового зловживання процесуальними правами;

- повторного чи систематичного неподання витребуваних судом доказів без поважних причин або без їх повідомлення;

- невиконання ухвали про забезпечення позову або доказів (ст. 149 КАС України) [1].

При цьому суд може скасувати постановлену ним ухвалу про стягнення штрафу, якщо особа, щодо якої її постановлено, виправила допущене порушення та (або) надала докази поважності причин невиконання відповідних вимог суду чи своїх процесуальних обов'язків (ч. 6 ст. 149 КАС України) [1]. Цей підхід підтримується у зарубіжній науковій думці. Зокрема, на переконання М. Болдвін, зменшити конфліктність судового провадження може запровадження положень про пільговий період, протягом якого сторона у справі або її представник може відкликати процесуальний документ, якщо протилежною стороною було порушене питання про його безпідставність та допущено тим самим зловживання процесуальними правами [11].

Також важливо зазначити, що вітчизняне законодавство встановлює можливість з урахуванням конкретних обставин справи стягнути штраф як з учасника справи, так і з його 
представника у разі невиконання процесуальних обов'язків, зловживання процесуальними правами представником учасника справи (ч. 3 ст. 149 КАС України) [1]. Водночас вітчизняне законодавство та судова практика не містять критеріїв, керуючись якими суд має визначати, чи накладати грошове стягнення лише на сторону у справі, чи лише на її представника, чи на їх обох одночасно.

Розмірковуючи над вищезазначеними питаннями, Ф. Талмадж, Е. Харт-Біберфельд та П. Лохнес вказали на те, що визначення особи, яка має бути піддана санкціям у конкретному випадку, визначається з урахуванням усіх обставин справи. Вченими висловлюється думка про те, що подання основних процесуальних документів лежить у сфері відповідальності представника сторони, якщо він $є$ професійним юристом, який, вочевидь, значно більш обізнаний із законодавством та юридичною практикою, несе більшу відповідальність. При цьому, якщо представник сторони має сумнів у наявності фактичних обставин та якості правового обгрунтування, необхідних для тих чи інших процесуальних дій, він зобов'язаний відмовитися від надання правової допомоги [8, с. 443], що відповідає п. 2 ч. 1 ст. 28 Закону України «Про адвокатуру та адвокатську діяльність». Більше того, за певних обставин не виключається навіть звернення санкцій за зловживання процесуальними правами також до юридичних фірм, якщо представник офіційно діяв як працівник юридичної фірми [8, с. 445]. Так само, за твердженням C. Нейбаргера, передусім, як правило, санкції мають застосовуватись до представників, оскільки несправедливим є поширення на сторін у справі наслідків поведінки їхніх представників, якщо лише вона не була схвалена або підтримана сторонами [10, с. 1054]. Застосування санкцій до сторони справи $€$ обгрунтованим, якщо, наприклад, сама сторона справи без відома представника підписала та подала процесуальний документ [8, c. 446].

Іншим питанням, яке слід порушити, вивчаючи аспекти застосування процесуального штрафу, є відповідність застосування цього заходу процесуального примусу та адміністративного штрафу за прояв неповаги до суду (ст. 185-3 Кодексу України про адміністративні правопорушення) за одне й те саме правопорушення (за повного збігу фактичних підстав для застосування цих примусових заходів). Так, на погляд Дж. Парнеса, враховуватись має принцип недопущення подвійної юридичної відповідальності за одне й те саме правопорушення [12, c. 1317].
Аналіз наукових джерел показує, що великого поширення набула думка про те, що застосування заходу процесуального примусу не виключає можливості застосування до особи, до якої було застосовано заходи процесуального примусу, заходів адміністративної відповідальності [9, с. 136]. Однак видається очевидним те, що немає підстав говорити про відмінність природи адміністративного стягнення у вигляді штрафу та штрафу як заходу процесуального примусу. Більше того, значною, якщо не повною, мірою збігаються склади правопорушень, вчинення яких тягне за собою адміністративний штраф та штраф у порядку процесуального примусу. Можливість іх застосування за одне й те саме правопорушення неодмінно порушує питання щодо того, чи має місце подвійна відповідальність, яке не може бути відкинуте через те, що законодавство не відносить процесуальний штраф до заходів адміністративної відповідальності.

Висловивши міркування щодо правового регулювання застосування таких заходів процесуального примусу, як попередження, видалення із залу судового засідання та штраф, зауважимо, що до сторін у справі можуть застосовуватись також такі законодавчо визначені заходи процесуального примусу:

- тимчасове вилучення доказів для дослідження судом - у разі неподання без поважних причин письмових, речових чи електронних доказів, що витребувані судом, або неповідомлення причин їх неподання (ст. 147 КАС України);

- привід - якщо явка сторони у справі була визнана обов'язковою (наприклад, на підставі п. 5 ч. 2 ст. 205 КАС України), але вона без поважних причин не прибула у судове засідання або не повідомила причини неприбуття (ст. 148 КАС України) [1].

Поряд із тим значний науковий інтерес становлять міркування вчених щодо підстав та способів застосування інших, крім процесуального штрафу, санкцій за зловживання процесуальними правами, якими є: покладення судових витрат повністю або частково незалежно від результатів вирішення спору на сторону чи її представника, що зловживали процесуальними правами (ч. 8 ст. 139 КАС України); постановлення окремої ухвали насамперед у разі зловживання процесуальними правами адвокатом або прокурором із іiї надісланням органу, до повноважень якого належить притягнення до дисциплінарної відповідальності прокурора або адвоката відповідно (ч. 3 ст. 249 КАС України); залишення без розгляду або повернення скарги, заяви, клопотання (ч. 3 ст. 45 КАС України). 
Так, залишення без розгляду або повернення скарги, заяви, клопотання у зарубіжній науковій літературі визнається найбільш суворою процесуальною санкцією. Розкриваючи їі сутність та призначення, Р. Рід вказав на те, що залишення позову сторони, яка допустила зловживання процесуальними правами, без розгляду не може прирівнюватись до відмови у правосудді, оскільки, коли учасник справи демонструє прагнення підірвати швидкий та справедливий судовий розгляд, зневажаючи правила судочинства та використовуючи суд для здійснення недоброчесних намірів, він не може очікувати на безперешкодну реалізацію права на правосуддя, яку має добросовісний учасник справи $[6$, с. 10,18$]$. Подібну позицію з цього питання висловив Г. Вульф, зазначаючи, що суд може залишити заяву без розгляду, якщо було вчинене несумісне з метою правосуддя правопорушення, яке надмірною затримкою або іншим чином надзвичайно ускладнюе або унеможливлює вирішення справи. За таких обставин єдиним кроком, який є доступним для судів та відповідає їх призначенню, $є$ припинення судового провадження, навіть за умови, що його завершення ухваленням остаточного судового рішення $є$ гіпотетично можливим. Нескінченно продовжувати тривалість судового провадження через недоброчесну поведінку учасників справи є недопустимим зловживанням судовим процесом [13]. Разом із тим, за слушним зауваженням Р. Ріда, залишення заяви без розгляду не є прийнятною санкцією за вияв неповаги до суду. Можливість припинити судове провадження $є$ знаряддям захисту судового процесу, а не покаранням учасників справи [6, с. 11]

Менш суворою процесуальною санкцією за зловживання процесуальними правами із вираженою компенсаційною спрямованістю $€$ покладення судових витрат повністю або частково незалежно від результатів вирішення спору на сторону чи її представника, що зловживали процесуальними правами. Видається очевидним те, що, передаючи на розгляд суду питання про компенсацію за зловживання процесуальними правами для процесуального опонента у рахунок покриття витрат на одержання правової допомоги, слід супроводжувати відповідне клопотання документом із розкриттям кількості витрачених робочих годин юриста, характеру діяльності. Разом із тим суд має самостійно визначити розумність зазначених показників та скоригувати відповідним чином розмір компенсації [8, с. 459-460].

Розглядаючи постановлення окремої ухвали, насамперед у випадку зловживання процесуальними правами адвокатом або прокурором із її надісланням органу, до повноважень якого належить притягнення до дисциплінарної відповідальності прокурора або адвоката відповідно, як санкцію за зловживання процесуальними правами, зауважимо, що у матеріалах зарубіжних наукових досліджень ця санкція вважається однією 3 немонетарних санкцій, що накладаються на юристів та стосуються права юриста брати участь у судових провадженнях у професійній якості, таких як, наприклад, зупинення права на заняття адвокатською діяльністю або позбавлення права на заняття адвокатською діяльністю [7, с. 210-211]. Разом із тим звертається увага на те, що для деяких адвокатів може бути цілком позитивною репутація винахідливого та орієнтованого на бажаний результат учасника судових проваджень, який може взяти на себе ризик зловживання процесуальними правами для реалізації ефективних з точки зору інтересів довірителів стратегій і тактик ведення справи, зазнаючи за це час від часу передбачених законом санкцій. Більше того, процедура притягнення представника до дисциплінарної відповідальності, яка може бути ініційована у зв'язку з допущеним представником зловживанням процесуальними правами, є тривалою та не обов'язково призведе до покарання представника, навіть якщо мало місце явне зловживання процесуальними правами [12, c. 1315]

\section{Висновки}

Підсумовуючи вищевикладене стосовно складу та змісту заходів процесуального примусу, що застосовуються до сторін в адміністративних справах, зазначимо, що такими заходами процесуального примусу $€$ попередження, видалення із залу судового засідання, тимчасове вилучення доказів для дослідження судом, привід, штраф. Зловживання сторонами в адміністративних справах процесуальними правами відповідно до вітчизняного законодавства про адміністративне судочинство може тягнути за собою залишення без розгляду або повернення скарги, заяви, клопотання; покладення судових витрат повністю або частково незалежно від результатів вирішення спору на сторону чи іï представника, що зловживали процесуальними правами; постановлення окремої ухвали насамперед у випадку зловживання процесуальними правами адвокатом або прокурором із її надісланням органу, до повноважень якого належить притягнення до дисциплінарної відповідальності прокурора або адвоката відповідно; штраф. За підсумками дослідження маємо підстави стверджувати, 
що правова основа 3 питань застосування вищенаведених примусових заходів є недосконалою, зокрема, у таких аспектах: можливість видалення сторони у справі із залу судового засідання; відсутність критеріїв стягнення процесуального штрафу лише 3 учасника справи, лише з його представника та з їх обох; недостатність положень про період, протягом якого особа може виправити допущене порушення для подальшого скасування судом ухвали про стягнення штрафу; можливість застосування процесуального штрафу та адміністративного штрафу за прояв неповаги до суду за одне й те саме правопорушення.

\section{Список використаних джерел:}

1. Кодекс адміністративного судочинства України : Закон України від 06.07.2005 № 2747-IV. Дата оновлення: 1 січня 2020 року. URL: https:// zakon.rada.gov.ua/laws/show/2747-15\#n9921 (дата звернення: 31.01.2020).

2. Кузьменко О., Панченко О. Особливості застосування заходів процесуального примусу в адміністративних судах головуючим у судовому засіданні. Право України. 2008. № 10. С. 31-37.

3. Кузьменко В.А. Застосування заходів процесуального примусу в адміністративному процесі : автореф. дис. ... канд. юрид. наук : 12.00.07. Київ, 2017. 20 с.

4. Завальнюк I.В. Примус в адміністративному процесі. Судово-юридична газета. 2018. № 34-35 (453-454). URL: https://sud.ua/ru/news/ publication/125004-primus-v-administrativnomuprotsesi (дата звернення: 03.02.2020).

5. Джафарова М. Загальна характеристика заходів процесуального примусу, які застосову- ються в адміністративному судочинстві. Підприємство, господарство і право. 2019. № 3. С. 143-147.

6. Reed R. Lies, Damned Lies: Abuse of Process and the Dishonest Litigant. 2012.18 p. URL: https:/ www.supremecourt.uk/docs/speech-121026.pdf. (дата звернення: 03.02.2020).

7. Richmond D. Alternative Sanctions in Litigation. New Mexico Law Review. 2017. № 209. URL: https://digitalrepository.unm.edu/nmlr/ vol47/iss2/2. (дата звернення: 31.01.2020).

8. Talmadge P., Hart-Biberfeld E., Lohnes P. When Counsel Screws Up: the Imposition and Calculation of Attorney Fees as Sanctions. Seattle University Law Review. 2010. Vol. 33:2. P. 437-461.

9. Пастернак В.M. Роль процесуального примусу в адміністративному судочинстві. Право $i$ суспільство. 2017. № 3 ч. 2. С. 134-137.

10. Neibarger G. Chipping Away at the Stone Wall: Allowing Federal Courts To Impose NonCompensatory Monetary Sanctions upon Errant Attorneys without a Finding of Contempt. Indiana Law Review. 2000. Vol. 33:1045. C. 1045-1076.

11. Baldwin M. Misconduct has its price: Sanctions against attorneys: MCLE Self-Assessment Test. 2016. URL: https://apps.calbar.ca.gov/ mcleselfstudy/mcle_home.aspx?testID=113 (дата звернення: 12.02.2020).

12. Parness J. The New Method of Regulating Lawyers: Public and Private Sanctions During Civil Litigation for Attorney Misconduct. Louisiana Law Review. 1987. Vol. 47. P. 1305-1317.

13. Arbuthnot Latham Bank Limited; Nordbanken London Branch v Trafalgar Holdings Limited; Ashton and Ashton: CA 16 Dec 1997. Times 29-Dec-1997, [1998] 1 WLR 1426, [1997] EWCA Civ 2999, [1998] 2 All ER 181. URL: https://swarb.co.uk/arbuthnotlatham-bank-limited-nordbanken-london-branch-vtrafalgar-holdings-limited-ashton-and-ashton-ca-16dec-1997/ (дата звернення: 12.02.2020).

It is noted that within the Ukrainian administrative justice system the following procedural sanctions could be imposed on parties: 1) an admonition; 2) a removal from the courtroom; 3) a temporary seizure of evidence for court investigation; 4) a forced transfer to the courtroom; 5) a fine. Abuse of procedural rights in accordance with the domestic legislation on administrative proceedings may entail: 1) dismissal of (striking out) the application, complaint or motion; 2) adverse costs order against the party or its representative, in whole or in part, irrespective of the outcome of the proceedings; 3) reference of professional representatives to their disciplinary body with a view to further action being taken; 4) fine.

However, several conclusions about the shortcomings of the legal framework regarding essence and grounds for imposition of these coercive measures are substantiated. In particular, it is argued that the removal of a party from the courtroom, especially, if he or she represents himself or herself without involving a legal professional makes it impossible to exercise her procedural rights during the hearing, which is incompatible with the principles of the adversarial proceeding and undermines the fairness of the trial. In addition, the fact that it is possible to impose a procedural fine and an administrative fine for contempt of court for the same offense is incompatible with the right not to be tried or punished twice. Attention is also drawn to the fact that domestic positive law and case-law do not contain criteria which guides the court in determining whether to impose a fine only on the party to the case, or only on its representative, or on both of them at the same time. Moreover, there is a loophole as to the period during which a person can remedy a violation for the further annulment of the decision and the refund of the fine.

Key words: procedural sanctions, fine, admonition, removal from the courtroom, dismissal of (striking out) the application, complaint or motion. 